\title{
The Effect of Federal Tax Deductibility on State and Local Taxes and Spending
}

\section{Citation}

Feldstein, Martin, and Gilbert Metcalf. 1987. The effect of federal tax deductibility on state and local taxes and spending. Journal of Political Economy 95(4): 710-736.

\section{Published Version}

http://dx.doi.org/10.1086/261482

\section{Permanent link}

http://nrs.harvard.edu/urn-3:HUL.InstRepos:2766699

\section{Terms of Use}

This article was downloaded from Harvard University's DASH repository, and is made available under the terms and conditions applicable to Other Posted Material, as set forth at http:// nrs.harvard.edu/urn-3:HUL.InstRepos:dash.current.terms-of-use\#LAA

\section{Share Your Story}

The Harvard community has made this article openly available.

Please share how this access benefits you. Submit a story.

Accessibility 


\section{The Effect of Federal Tax Deductibility on State and Local Taxes and Spending}

\section{Martin S. Feldstein and Gilbert E. Metcalf}

Harvard Unversity and National Bureau of Economic Research

This paper examines the effect of federal deductibility of state and local taxes on the fiscal behavior of state and local governments. The primary finding is that deductibility affects the way that state and local governments finance their spending as well as the overall level of spending. More specifically, in states in which federal deductibility implies a relatively low cost of using deductible personal taxes (including income, sales, and property taxes), there is greater reliance on those taxes and less reliance on business taxes and other revenue sources. The effect of deductibility on the state and local financial mix implies that deductibility has a much lower cost to the federal government than has previously been assumed.

The deductibility of state and local tax payments in the calculation of federal personal income tax liabilities is one of the key features of the fiscal relation between the federal government and the governments of states and localities. For 1984, deductions for state and local personal taxes directly reduced federal tax revenues by an estimated $\$ 30$ billion, more than 30 percent of the federal grants to state and local governments (Office of Management and Budget 1985). When the

We are grateful to Daniel Feenberg for help with the TAXSIM calculation reported in Secs. III and IV. We have also benefited from comments by participants in the NBER Tax Program and from additional discussions with Robert Inman and Lawrence Summers. This paper is part of the NBER Study of the Government Budget and the Private Economy and of the Study of State and Local Public Finance. An earlier and more complete version of the present paper is available from the National Bureau of Economic Research as Working Paper no. 1791.

[Journal of Political Econowy, 1987, vol. 95, no. 4]

O 1987 by The University of Chicago. All rights reserved 0022-3808/87/9504-0002\$01.50 
Reagan administration proposed to eliminate state and local deductibility as part of its November 1984 tax reform proposal, the state and local governments objected that deductibility is needed to maintain public support for existing spending levels of important state and local activities and that eliminating deductibility would subject taxpayers to unfair double taxation. The Treasury Department agreed that the current deductibility raises state and local spending but argued that this is a tax-induced distortion in the allocation of resources that should be eliminated. The Treasury also asserted that the deductibility provision causes a large loss of federal revenue and is of primary benefit to high-income taxpayers. ${ }^{1}$

The sensitivity of state and local taxes and spending to deductibility is therefore a crucial part of the arguments of both the advocates and the critics of deductibility. Unfortunately, very little is known about the quantitative effects of the current tax deductibility rule on the behavior of state and local governments. The purpose of the present paper is to make a first contribution toward remedying that deficiency.

The paper gives particular attention to the possibility that the deductibility of personal tax payments affects the way that state and local governments finance their spending as well as the amount of that spending. Separate equations are estimated for (1) per capita state and local personal income and sales taxes; (2) per capita state and local revenues that are not deductible in the calculation of personal tax liabilities, including corporate taxes, taxes on motor vehicle fuels, license and user fees, and so forth; and (3) the level of per capita state and local spending.

The econometric evidence indicates that deductibility has a powerful effect on the extent to which states and localities use deductible personal taxes. The effect of deductibility on the overall level of spending by states and localities is more uncertain. Deductibility may cause states and localities to rely more heavily on the deductible personal taxes than on other types of revenue. The estimates suggest that eliminating personal tax deductibility might raise federal tax revenue by only a small fraction of the amount predicted by the traditional "static" revenue estimates and might actually reduce it. ${ }^{2}$

${ }^{1}$ The Treasury arguments are presented in U.S Department of the Treasury (1984) and Office of the President (1985). For useful summaries of the traditional arguments for and against deductibility, see Bridges (1966), Bartlett (1985), and Billman and Cunningham (1985). See also the comments of Break (1985) and Gramlich (1985b).

2 The analysis in this paper is thus another example of the importance of going beyond the traditional static revenue estimation procedures and incorporating realistic behavioral assumptions in tax policy analysis. For further examples of behavioral simulation methods in tax policy analysis, see Feldstein (1983). 


\section{The Theory of the Effect of Federal Tax Deductibility on State and Local \\ Taxation and Spending}

Before we consider the choice process of the state or local community, it is useful to begin by examining how federal tax deductibility affects the preferences of a single individual who itemizes his tax deductions in calculating his federal tax liability. If individual $i$ is an itemizer with marginal tax rate $m_{v}$, the deductibility of state and local taxes means that an additional dollar of state or local tax payment reduces the individual's federal tax liability by $m_{i}$ dollars. The net cost to the individual of paying one dollar to the state or local government is thus $1-m_{i}{ }^{9}$ We will call this the federal tax price of state and local taxes for individual $i$. Since the average marginal tax rate for itemizers is 27 percent, the average federal tax price among itemizers is 0.73 , a substantial reduction in the price of state and local tax revenue. ${ }^{4}$ Of course, a nonitemizer's federal tax liability is unaffected by his payments of state and local taxes; his federal tax price is therefore 1 .

A lower federal tax price for state and local personal taxes increases the individual's preferred level of state and local spending. It also causes the individual to prefer to finance those services with greater reliance on deductible personal taxes rather than personal user charges (which are not deductible) or corporate taxes and fees (which could reduce wages or cause corporations to leave the state or locality). To the extent that the net costs to the individual of the different sources of state and local finance are initially perceived to be approximately equal, a change in the federal tax price for a state or locality could cause a substantial substitution of one type of finance for another without any significant change in the perceived cost of funds and therefore without any significant change in the desired level of spending. This combination of a sensitive composition of finance and an insensitive level of spending is characteristic of the evidence presented below.

The measurement and interpretation of the federal tax price of personal tax revenue become more complicated when we shift attention from the preferences of a representative itemizer to the decision of the community as a whole. If a proportion $p$ of individuals itemize, the average federal tax price is $1-p+p(1-m)=1-p m$. Since only about 30 percent of taxpayers itemize their tax deductions, the

\footnotetext{
${ }^{3}$ This ignores the fact that local and federal taxes are deductible in calculating taxable income under some state income tax rules.

4 The 27 percent is a weighted average marginal tax rate, weighted by the amount of state and local taxes deducted. Thus federal revenue is directly reduced by 27 percent of total personal deductions of state and local taxes.
} 
average federal tax price is about $1-0.3(0.27)=0.92$. The average price reduction is clearly much smaller than the price reduction for itemizers.

Which of these two prices-the average tax price or the tax price of itemizers-is relevant for local government decisions? Or do decisions depend in a more complex way on the entire distribution of individual tax prices? There is, unfortunately, no agreement among specialists in state and local public finance about the relation between local government fiscal decisions and the preferences of the individual voters in the constituency. ${ }^{5}$

Feldstein and Metcalf (1986) show that even in the simple median voter model there is substantial ambiguity about the effect of eliminating deductibility on the community's choice of spending level. Within the median voter model, the effect of eliminating deductibility depends on whether the median voter is initially an itemizer and on whether the change in deductibility alters the identity of the median voter. That analysis shows that if an itemizer is initially the median voter and remains the median voter when deductibility is eliminated, a quite modest individual price elasticity would imply a relatively large aggregate price elasticity. More generally, however, if eliminating deductibility would change the identity of the median voter, the aggregate price elasticity might be smaller or larger than the price elasticity of the typical individual. It is clear from these comments that, even in the context of the median voter model with all spending financed by deductible personal taxes, it is wrong to use the previously estimated price elasticities of demand to evaluate the likely impact of changing the federal tax deductibility of state and local taxes. ${ }^{6}$

The median voter model also has potentially important but generally ambiguous implications about the effect of deductibility on the community's preference for using personal taxes to finance state and local spending. The chosen mix of revenue sources will reflect such things as whether the median voter is an itemizer, the progressivity of the personal tax, and the nature of the alternatives to personal taxation as a source of revenue. Moreover, it is impossible to know from a priori considerations alone how changes in deductibility that affect the chosen mix of financing will alter the resulting level of state and local spending.

\footnotetext{
${ }^{5}$ For surveys of the empirical evidence on this issue, see Inman (1979) and Rubinfeld (1986).

${ }^{6}$ Several studies have done just that. These include Ladd (1984), Noto and Zimmerman (1984), and the Congressional Research Service study prepared for the Senate Committee on Government Operations by Noto and Zimmerman (1983). Gramlich (1985a) used microeconomic price elasticities but did so in a theoretically correct way by calculating individual demands for a representative sample of voters and then finding the demand of the median voter in this sample.
} 
Although the median voter model is analytically attractive, it is clearly not rich enough to deal with a variety of aspects of actual state and local spending and tax issues. In general, the local government must make a variety of interrelated but separate tax and spending decisions. An important feature of such decision making may be logrolling, coalition formation, and the development of stable political parties in which different voter subgroups support each other's preferred projects and compromise on a package of tax sources. In addition, a number of studies have pointed to the bureaucracy and to the politically elected officials as independent sources of influence on budgetary choices. And, finally, the process of majority choice may induce migration among jurisdictions that changes the composition of each area's voting group and therefore the outcome of the voting process. ${ }^{7}$

Because of the difficulty of deriving a satisfactory theoretical model of the effects of deductibility on state and local fiscal choices, we have extended the conventional empirical specification of local government spending to include two alternative descriptions of the effect of federal tax deductibility. The first specification includes the average federal tax price in the state while the second specification includes both the proportion of individuals who itemize and the average tax price of itemizers. Since both specifications give very similar results, we conserve space here by presenting only the results for the composite average federal tax price variable; estimates based on the alternative specification are presented in Feldstein and Metcalf (1986).

\section{Previous Research on the Effects of Federal Tax Deductibility}

Most previous research on the effects of federal tax deductibility has ignored the impact of deductibility on the mix of state and local revenue sources and focused instead on estimating the effect of deductibility on the level of state and local spending. Moreover, these studies have used price elasticities of demand for local spending based on interjurisdictional differences in the cost of buying public services that arise because of intergovernmental matching programs or interjurisdictional differences in the costs of producing public services. $^{8}$ Since these sources of differences in the costs of public services affect

${ }^{7}$ For a discussion of these issues, see Inman (1979, 1986).

8 This comment applies to the studies by Noto and Zimmerman $(1983,1984)$ and Ladd (1984). Gramlich (1985a) correctly aggregated the micropreferences within the framework of the median voter model; his analysis is, however, restricted by the use of the median voter model and by the assumption that the amount of revenue from sources other than deductible personal taxes is fixed. 
all taxpayers equally, they provide little information about the likely impact of a change in the federal tax price that would affect only those taxpayers who itemize or that would alter the mix of financing.

Inman (1985) has provided the only explicit econometric study of the effect of the federal deductibility of local taxes. His study examined the experience of 41 large cities during the years 1960-80 and estimated the price elasticities of local spending and tax revenue with respect to an estimate of the local average federal tax price. The resulting parameter estimates are puzzling, with signs or the key tax price variables that are the opposite of what would be expected. For example, Inman found that a higher tax price for property taxes reduces the use of income and sales taxes and that a higher tax price for income and sales taxes reduces the use of the property tax. It seems likely that these surprising results reflect two serious problems in Inman's procedure.

First, the basic data needed to estimate the federal tax prices (i.e., the actual federal marginal tax rates and itemizer status for individuals in these cities) are not available. Inman's solution to this serious problem was to combine the Census Bureau estimates of the income level at the twenty-fifth, fiftieth, and seventy-fifth percentile points of each city's income distribution with the tax rate at that income level and the national proportion of itemizers to create an estimated tax price. Although this method is probably the best that could be used to estimate tax prices at the city level, the result is clearly a very imperfect measure. There is no information on high-income individuals, who make up the bulk of the itemizers, and therefore no information on the average tax rate of itemizers. Imputing a probability of itemization on the basis of national totals ignores the likelihood that middle- and upper-middle-income individuals are probably less likely to itemize if they are urban renters than if they are homeowners and that homeownership and other factors affecting itemization may vary significantly among cities.

The second problem with Inman's procedure is that it focuses on city budgets when the division of spending responsibilities and of tax bases between city and state levels of government varies enormously among the states. In some states, the cities have a great deal of autonomy in setting taxes and are responsible for spending on a wide range of programs. In other states, the state government restricts the taxing authority of the cities, assumes financial responsibility for most types of government services, and influences local activity by regulations and matching grants. In Massachusetts, for example, cities are precluded from setting income or sales taxes and are subject to a maximum rate on their local property tax; the state shares its tax revenue with the cities through block grants and educational matching grants 
and assumes full responsibility for general welfare. Arrangements such as these, which obviously influence taxes and spending at the city level, must be taken into account in specifying the city tax and spending equations in order to obtain unbiased estimates of the price elasticities of demand. Although Inman has great expertise about these provisions and uses the available data skillfully, the interstate differences in state and local institutional arrangements are just too complex to be modeled adequately in Inman's econometric equations. The inability to incorporate these institutional arrangements into the estimating structure makes it very difficult to interpret the estimated price elasticity of demand and the implied estimates of the effect of eliminating federal tax deductibility.

A second recent study by Hettich and Winer (1984) attempts to assess how federal deductibility and other variables affect the share of state taxes derived from the personal income tax. Although the authors provide an interesting analysis of local tax decisions as the outcome of choices by public decision makers subject to political constraints, their empirical work has four severe limitations. First, the role of deductibility is measured very crudely by the percentage of taxpayers in the state with incomes greater than $\$ 20,000$. There is no information on itemization and no assessment of the marginal tax rates. The estimated coefficient of this variable is statistically insignificant and has the wrong sign. Second, the analysis refers to the share of personal income taxes in the state's tax revenue rather than to the share of income, property, and sales taxes, all of which are deductible. Third, the focus is on the state rather than on the combined state and local fiscal decision. Finally, the authors include state expenditure per capita among the regressors. This is a potential source of very substantial simultaneous equation bias affecting all the coefficients. More generally, it is not clear why the spending level should be taken as logically prior to the composition of taxes. A better specification with the cross-section sample would be simultaneous choice, with neither taxes nor spending among the regressors. With all these problems, it is not surprising that the estimated effect of deductibility on the composition of the tax revenue is estimated to be insignificant and of the wrong sign.

The only other study that we know of that deals empirically with the effect of deductibility on the state and local tax structure is the work of Zimmerman (1983). He elaborates a median voter model and then concludes, on the basis of his statistical evidence, that federal deductibility has no statistically significant effect on the ratio of the state and local taxes paid by the median income family to the average over all families of the state and local taxes paid in the state. There are a number of problems with the specification that make it difficult to 
interpret this finding. Zimmerman included the average public-sector wage and the level of state and local spending among the regressors, although both would probably be very endogenous. In addition, the federal tax price variable was calculated only for the median voter, who Zimmerman arbitrarily assumes is the same as the medianincome family. If the actual decision process gives weight to others as well, the tax price of the median voter may be too restrictive a specification. In particular, the empirical analysis makes no allowance for the effect of differences in the relative frequency of itemizers among states. The absence of this source of variation in the average tax price may explain why his federal deductibility variable "apparently does not possess sufficient variation ... to make it a significant determinant" (p. 193).

We have concluded that, because of the shortcomings of previous estimates of the price elasticity and because of the special problems of analyzing a policy change that affects only itemizers, there are currently no useful estimates on which to base an analysis of the likely effects of changes in the federal deductibility of state and local taxes.

\section{Using Federal Tax Prices Based on Individual Tax Return Data to Estimate Tax and Spending Behavior of State and Local Governments}

In the present paper, we use observations for a cross section of states to estimate the effect of the federal tax price on the combined total of state and local personal taxation in each state as well as on aggregate state and local spending in the state. ${ }^{9}$ By combining state and local levels in this way, we avoid the problem of institutional differences in the assignment of spending and tax responsibilities. In effect, our specification treats the assignment of such responsibilities as an endogenous behavior that is influenced by such variables as the federal tax price and the distribution of income. Our estimates are therefore in the nature of reduced-form equations that relate spending and taxes within each state (including both the state and local levels of government within the state) to the price, income, demographic, and environmental variables that characterize the state.

The statistical analysis presented below relates to three state and

\footnotetext{
${ }^{9}$ The empirical analysis of this paper differs from Feldstein and Metcalf (1986) in two ways. The most important of these is recognizing that selective sales taxes (like the gasoline fuel tax) should not be included in personal deductible taxes. The second is to use the TAXSIM model for calendar year 1979 instead of 1980 in order to avoid having the explanatory variable based on a later time than the 1980 fiscal year dependent variables.
} 
local fiscal variables: (1) the combined state and local revenue from personal deductible taxes including income taxes, sales taxes, and property taxes; (2) all other state and local revenue, including corporate income taxes, severance taxes, license fees, special excise taxes that are not deductible on personal tax returns, and gift and estate taxes; and (3) the spending financed from state and local resources. The third variable is thus the sum of the first two. Specifically excluded are all forms of federal aid.

The state and local revenue from potentially deductible personal taxes in fiscal year 1980 averaged $\$ 698$ per capita with a standard deviation of $\$ 198$. This represents an average of 7.5 percent of personal income with a standard deviation of 1.5 percent. The remaining state and local revenue averaged $\$ 556$ per capita with a standard deviation of $\$ 492$. This corresponds to an average of 5.9 percent of personal income with a standard deviation of 3.7 percent. Finally, total spending financed by own revenue is the sum of these two revenue sources, $\$ 1,254$ per capita or 13.4 percent of income. The standard deviation of total spending is $\$ 595$ or 4.1 percent when calculated as a percentage of income. The per capita levels and income shares for the three fiscal variables are presented in Feldstein and Metcalf (1986).

The key federal tax price variable for each state was calculated using individual federal income tax returns. More specifically, the federal tax price data were generated by the National Bureau of Economic Research (NBER) TAXSIM model with data for 1979. The TAXSIM model incorporates 21,787 individual tax returns, a one-ineight random sample of those provided by the Internal Revenue Service, and a computer program that can calculate each taxpayer's liability under existing and alternative tax laws. Since sample weights and state identifiers are provided, this sample can be used to estimate average characteristics of the taxpayers of each state. This use of individual tax returns is a unique advantage of the current data over previous studies that had to use various measures of aggregated data or representative individuals to estimate tax rates for each state (e.g., Phares 1980; Inman 1985).

For each individual, the federal tax price is defined as one if the individual is a nonitemizer and as one minus the decrease in federal tax liability per dollar increase in itemized deductions for an individual who itemizes. ${ }^{10}$

${ }^{10}$ In general, the tax price for an itemizer is one minus the individual's marginal tax rate, but the calculation is more complex for individuals who are income averagers, are subject to the alternative minimum tax, or are in other special situations. The TAXSIM program calculates the correct federal tax price by increasing the individual's itemized deductions by $\$ 100$, recomputing the individual's tax liability, and dividing the difference in tax liability by $\$ 100$. 
Appendix table Al shows the federal tax price for each state, the proportion of taxpayers who itemize, and the federal tax price for those itemizers. The average value of the federal tax price is 0.92 , implying that federal tax deductibility reduces the cost of state and local spending by an average of 8 percent. The federal tax price ranges from a low of 0.87 in Alaska to a high of 0.97 in South Dakota with a standard deviation of 0.02 . Much of the variation in the federal tax price reflects interstate differences in the proportion of itemizers, which varies from a low of 14 percent in South Dakota to a high of 44 percent in Michigan with a standard deviation of 6.6. The average federal tax price among itemizers varies from a low of 0.67 in Alaska to a high of 0.78 in Montana with a standard deviation of 0.02 .

The econometric estimates relate each of the three state and local fiscal measures to the federal tax price, to per capita income, and to several other economic and demographic characteristics of the state. Two alternative specifications are examined. In the income share equations, the dependent variable is the ratio of each fiscal variable to average personal income in the state, and the price variable is the average federal tax price in the state. In the constant price elasticity equations, the dependent variable is the logarithm of the per capita value of the fiscal variable (e.g., the logarithm of per capita state and local personal taxes) and the price variable is the logarithm of the federal tax price.

The income variable used in these analyses is the census definition of average per capita personal money income. Most of the other variables included in the estimation equations are the familiar explanatory variables of previous studies of state and local spending. These include the number of pupils per capita, the road mileage per capita, and the proportions of the population who are aged, in poverty, homeowners, living in urban areas, married, and nonwhite. ${ }^{11}$ In addition to these variables, we have also used the NBER TAXSIM model to derive several measures of the distribution of income in each state: the variance and skewness of the income distribution; the average ratio of dividends to adjusted gross income; the average ratio of capital gains to adjusted gross income; and the percentages of taxpayers with adjusted gross incomes in the ranges $\$ 7,500-\$ 15,000, \$ 15,000$ $\$ 25,000, \$ 25,000-\$ 35,000, \$ 35,000-\$ 50,000$, and over $\$ 50,000$.

\section{A Problem of Statistical Endogeneity}

There is a serious problem in using any of these federal tax price variables to estimate the effect of federal tax deductibility on the level

11 Sources of these variables are listed in app. table A-3 of Feldstein and Metcalf (1986). 
of state and local personal taxes. To understand the nature of this problem, consider a simplified specification of our basic equation. If $T_{i}$ is the per capita level of personal taxes in state $i, P_{1}$ is the federal tax price, and $Y_{\imath}$ is per capita income, a constant elasticity specification is given by

$$
\ln T_{i}=a_{0}+a_{1} \ln P_{1}+a_{2} \ln Y_{i}+u_{i},
$$

where $u_{3}$ is a stochastic disturbance that reflects tastes and other unobserved factors influencing the level of state and local taxation in state $i$.

Ordinary least squares estimation gives unbiased parameter estimates only if the stochastic disturbances are statistically independent of the price and income variables. Consider what happens if the individuals in state $i$ have a greater than normal preference for relying on personal taxes to finance state and local services $\left(u_{i}>0\right)$. A higher level of state and local personal tax revenue per capita raises the typical individual's potential itemized deductions and makes it more likely that individuals in that state will find it optimal to itemize their federal tax return. This has the effect of lowering the federal tax price for that state. Thus, to the extent that a positive taste for financing state and local services by personal taxes reduces the federal tax price, it induces a negative correlation between the price variable and the unobservable stochastic disturbance. In short, the price variable is endogenous, and standard econometric theory tells us that the estimated price elasticity ( $a_{1}$ in eq. [1]) will be biased in a negative direction; that is, the negative price elasticity will be overstated in magnitude.

The reason for this statistical bias is easy to see. Consider what would be observed if state and local governments were not at all sensitive to the federal tax prices of their residents when deciding how much to spend and how to finance that spending. Since an aboveaverage taste for state and local services financed by personal taxes would lead to increased itemization and therefore a lower federal tax price, there would still be a negative relationship between personal taxes and the federal tax price. The statistical estimation procedure would interpret this negative relation incorrectly as a measure of the sensitivity of state and local personal taxes to the federal tax price even though, in this case, there is no behavioral relation between the federal tax price and the level of state and local personal taxes. More generally, when a lower federal tax price does increase the chosen level of state and local personal taxation, the simultaneous effect of state and local taxation on the federal tax price will lead to an exaggerated estimate of the effect of the federal tax price on the tax and spending decisions of state and local governments. 
Even when we look only at itemizers, there is a relationship between the unobservable disturbance and the federal tax price. A positive disturbance raises per capita state and local personal taxes, thereby increasing the itemized deduction of those who itemize and tending to move them into lower federal marginal tax rate brackets. For an itemizer, a lower marginal tax rate means a higher federal tax price. Thus, for itemizers, an above-average taste for state and local services raises the federal tax price and tends to diminish the absolute magnitude of the estimated price elasticity.

Since the statistical bias that operates through the increased probability of itemizing is in the opposite direction of the effect through the marginal tax rate of itemizers, the sign of the bias cannot be determined a priori. However, since the variability and importance of itemization are substantially greater than the variability of the marginal tax rate of itemizers, it seems likely that the itemization bias will dominate. The evidence presented below indicates that this is so, causing the estimated coefficient to be biased toward a more negative (absolutely larger) value.

Although ordinary least squares estimation results in a statistically biased estimate of the effect of the federal tax price variable, a consistent and asymptotically unbiased estimate can be obtained by using an instrumental variable procedure with an appropriate instrument for the federal tax price variable. An appropriate instrumental variable is any variable that is uncorrelated with the stochastic disturbance term $\left(u_{1}\right)$ but correlated with the exogenous component of the federal tax price variable.

We have used the TAXSIM sample of individual tax returns to construct a set of instrumental variables that are correlated with the exogenous component of the federal tax price and, as far as possible, uncorrelated with the unobserved stochastic "taste" disturbance term. To compute the first such instrumental variable, we began by excluding the deduction for state and local taxes from all itemized tax returns. We then calculated the marginal tax rate for each tax return, including both itemizers and nonitemizers. Next we assigned to each tax return a probability of being an itemizer based only on the adjusted gross income (AGI) class of the return (using eight AGI classes) and the national proportion of taxpayers in that AGI class who itemize. An average marginal tax rate was then calculated for each state with each tax return for that state weighted by that return's probability of itemizing as well as by a weight that correctly adjusts for the stratified random sample. This itemization-weighted marginal tax rate was subtracted from one to form a type of tax price variable. For an individual who itemizes his deductions, this procedure corresponds to calculating the tax price associated with the first dollar of 
state and local tax deduction; we will therefore refer to this as a firstdollar tax price instrument. Note that this variable reflects the marginal tax rates of all taxpayers and not just of those who itemize. Because the synthetic probability of itemization was used, the variable is not sensitive to the actual rate of itemization in the state.

It might, of course, be objected that there is still some possible endogeneity in this instrumental variable, that is, some correlation between the instrument and the taste disturbance in the behavioral equation. Even when state and local deductions are ignored, the weighted average marginal tax rate reflects the level and distribution of income in the state and such demographic variables as the proportion of aged persons in the population, the number of children, the relative number of homeowners, and so forth. Since these variables also potentially affect the demand for local services and, arguably at least, the reliance on personal taxes, the instrumental variable would be correlated with the disturbance in the equation. To reduce or eliminate this problem, these variables were explicitly included among the regressors in the specification of the equation.

The second instrumental variable is similar to the first in all respects except that, instead of replacing each itemizer's state and local tax deduction with zero, we replaced it with the national average state and local deduction for individuals in that AGI class. We refer to this as the average dollar tax price instrumental variable.

Our third instrumental variable is the proportion of taxpayers in the state who would be expected to itemize if each taxpayer's probability of itemizing were equal to the national average for his AGI class. This is clearly uncorrelated with the taste factors peculiar to each state and depends only on a particular nonlinear configuration of the state's distribution of AGI. Since several variables representing the size distribution of money income were explicitly included among the regressors in the equations presented in the next section, the disturbance term can reasonably be presumed to be free of the effects of income distribution that are the basis of this instrumental variable. More generally, this instrumental variable gets its identifying power from the difference between AGI and money income and from the particular nonlinear relation between AGI and itemization. Finally, two further instrumental variables have been constructed: the average first-dollar tax price among itemizers only and the average dollar tax price among itemizers.

In summary, the instrumental variables, unlike the tax price variable itself, do not directly reflect the proportion of individuals in each state who itemize or the deductions for state and local taxes within that state. They are correlated with the federal tax price variable for each state to the extent that that variable reflects the distribution of 
TABLE 1

Effects of Federal Deductibility on State and Local Taxes and Spending

\begin{tabular}{|c|c|c|c|c|c|}
\hline \multirow[b]{3}{*}{ Dependent Variable } & \multicolumn{3}{|c|}{$\begin{array}{c}\text { Ratio } \\
\text { SPECIFICATION }\end{array}$} & \multicolumn{2}{|c|}{$\begin{array}{l}\text { LogarithMiC } \\
\text { SPECIFICATION }\end{array}$} \\
\hline & \multicolumn{2}{|c|}{$\begin{array}{c}\text { All } \\
\text { Variables }\end{array}$} & \multirow{2}{*}{$\begin{array}{c}\text { Restricted } \\
\text { Variables: } \\
\text { IV } \\
\text { (3) }\end{array}$} & \multirow{2}{*}{$\begin{array}{c}\text { All } \\
\text { Variables: } \\
\text { IV } \\
\text { (4) }\end{array}$} & \multirow{2}{*}{$\begin{array}{c}\text { Restricted } \\
\text { Variables: } \\
\text { IV } \\
\text { (5) }\end{array}$} \\
\hline & $\begin{array}{l}\text { OLS } \\
(1)\end{array}$ & $\begin{array}{l}\text { IV } \\
(2)\end{array}$ & & & \\
\hline Personal taxes & $\begin{array}{r}-.48 \\
(.17) \\
{[-5.99]} \\
\{1.16\}\end{array}$ & $\begin{array}{r}-.42 \\
(.28) \\
{[-5.24]} \\
\{1.17\}\end{array}$ & $\begin{array}{c}-.24 \\
(.15) \\
{[-3.00]} \\
\{1.18\}\end{array}$ & $\begin{array}{r}-4.74 \\
(3.72) \\
\{.16\}\end{array}$ & $\begin{array}{r}-2.99 \\
(2.01) \\
\{.16\}\end{array}$ \\
\hline $\begin{array}{l}\text { Other state and local } \\
\text { revenue }\end{array}$ & $\begin{array}{r}-.02 \\
(.19) \\
{[-.34]} \\
\{1.31\}\end{array}$ & $\begin{array}{r}-.15 \\
(.32) \\
{[-2.56]} \\
\{1.33\}\end{array}$ & $\begin{array}{c}.20 \\
(.17) \\
{[3.41]} \\
\{1.29\}\end{array}$ & $\begin{array}{c}.28 \\
(5.85) \\
\{.25\}\end{array}$ & $\begin{array}{c}1.72 \\
(2.98) \\
\{.24\}\end{array}$ \\
\hline $\begin{array}{l}\text { Net state and local } \\
\text { spending }\end{array}$ & $\begin{array}{r}-.50 \\
(.22) \\
{[-3.60]} \\
\{1.52\}\end{array}$ & $\begin{array}{r}-.57 \\
(1.37) \\
{[-4.11]} \\
\{1.53\}\end{array}$ & $\begin{array}{c}-.04 \\
(.20) \\
{[-.29]} \\
\{1.55\}\end{array}$ & $\begin{array}{c}-2.41 \\
(2.84) \\
\{.12\}\end{array}$ & $\begin{array}{c}-.50 \\
(1.49) \\
\{.12\}\end{array}$ \\
\hline
\end{tabular}

Nore.-All coefficients are of the tax pnce vanable; see the text for a descripuon of other vartables and App table $\mathrm{A} 3$ for their coefficients, standard errors are shown in parentheses, standard error of the regression in braces For the ratio specification, the elasuctues of the mean values are shown in brackets

taxable income and other characteristics of the taxpayers in the population. The values of the instruments are presented in Appendix table A2.

\section{The Statistical Estimates}

The estimated coefficients of the tax price variable corresponding to different dependent variables and different specifications are presented in table 1. These estimates are based on data for the 48 contiguous states. The first three columns refer to the ratio specifications in which the dependent variable is expressed as a fraction of personal income, for example, personal taxes per dollar of taxable income. The last two columns refer to the logarithmic constant elasticity specification. The coefficients of the other variables corresponding to columns 1-3 are presented in Appendix table A3. The coefficients for the equations of the other columns are available from the authors.

Consider first the coefficient of the tax price in the equation in which the dependent variable is personal taxes per dollar of personal income. When all the potential explanatory variables described in Section 1 II are included in the specification and the equation is estimated by ordinary least squares (OLS), the estimated coefficient of 
the tax price variable is -0.48 with a standard error of 0.17 . This is shown in the first column and first row of table 1.

Before we look at any of the other estimated coefficients, it is interesting to calculate the elasticity of personal taxes with respect to the federal tax price that corresponds to this coefficient. Since the mean value of the tax price variable for the $\mathbf{4 8}$ contiguous states is 0.92 and the mean value of personal taxes per dollar of personal income is 0.075 , the elasticity at these mean values is -5.99 ; this figure is shown in brackets beneath the standard error of the coefficient. Although -5.99 seems like a very high elasticity, it is important to stress that it is an elasticity of demand not for state and local services but for taxdeductible personal taxes used to finance state and local spending. ${ }^{12}$

When the same specification is estimated by an instrumental variable (IV) procedure using the instrumental variables described in the previous section, the coefficient shifts from -0.48 to -0.42 with a standard error of 0.28 . This IV estimate is shown in the second column of table 1 . The rise in the value of the coefficient reflects the OLS bias discussed in the previous section. It implies that the positive correlation between a taste for personal tax-financed spending by state and local governments and the resulting higher level of itemization outweighs the negative correlation between the taste for personal tax-financed spending by state and local governments and the resulting lower level of the marginal tax rate of itemizers.

The specification in columns 1 and 2 includes all 19 variables described in Section III, including nine variables that describe the distribution and composition of income. Since there are only 48 observations, the coefficients of most of these 19 regressors are smaller than their standard errors. In general, the variables for which the coefficient is at least 1.5 times its standard error are the number of pupils per capita, the percentage of the population in the state living in urban areas, the percentage of the population that are aged, and the percentage of the population that own their own homes. Restricting the regressors to these four variables in addition to per capita income and the federal tax price yields the tax price coefficients presented in columns 3 and $5 .{ }^{\text {Ig }}$

In the ratio specification, the tax price coefficient declines to -0.24 with a standard error of 0.15 . The implied elasticity of -3.00 is very

${ }^{12}$ Moreover, Feldstein and Metcalf (1986) show that in a median voter model (with realistic values of the tax parameters) the aggregate price elasticity is approximately three times the elasticity of the individual median voter.

${ }^{13}$ On the question whether or not to exclude variables in order to reduce the mean square error of the coefficient of interest, see Feldstein (1973) and Madalla (1977, chap. 10). 
similar to the constant elasticity of -2.99 estimated with the logarithmic specification and presented in column 5 . Restricting the number of regressors generally has the advantage of reducing the standard errors of the remaining coefficients, something that is particularly useful in the context of IV estimation, but also adds to the risk that the coefficient estimates are biased.

To assess the importance of the tax price coefficient, recall that the average tax price variable is 0.92 and that, on average, the ratio of personal taxes to personal income is $\mathbf{0 . 0 7 5}$. The coefficient of the tax price variable in the IV equation with all the explanatory variables present implies that eliminating deductibility (i.e., increasing the federal tax price to 1.0 ) would reduce the ratio of personal taxes to personal income by $0.08 \times 0.42=0.034$, or about one-half of the existing level. The restricted specification of column 3 has a smaller coefficient $(-0.24)$ and therefore implies that eliminating deductibility would reduce the ratio of personal taxes to income by $0.08 \times 0.24$ $=0.020$, or about one-fourth of the existing level. Thus both equations imply a quite substantial reduction in state and local deductible personal taxes.

The estimated effects of the federal tax price on all other types of state and local revenue are more ambiguous. In the IV regression with all the explanatory variables, the coefficient of the federal tax price has the wrong sign and is less than half of its standard error. Taken at face value, this implies that the reduction in personal taxes is not offset by an increase in other types of revenue but results in an equivalent reduction in state and local spending. But when the set of explanatory variables is restricted to those with a $t$-statistic of at least 1.5 (col. 3 of table 1), the estimated coefficient of the federal tax price variable has the expected positive sign and is slightly larger than its own standard error. Moreover, the standard error of the regression is smaller for this restricted regression than for the regression with all the explanatory variables. Acceptance of this specification implies that the reduction in personal taxes is offset by an almost equal increase in other types of revenue, leaving total spending unchanged. There is, unfortunately, no way to reduce this ambiguity with the available data.

Since the net public spending financed by state and local resources is equal to the sum of personal taxes and other state and local revenue, the coefficients of the tax price variable in the ratio specifications of columns 1-3 are the sums of the coefficients in the two tax equations. Thus, in the specification with all variables included (col. 2), the tax price coefficient implies a substantial reduction in net state and local spending while, with the restricted set of explanatory variables, the tax price appears to have no effect on net spending. The 
logarithmic specifications of columns 4 and 5 do little to reduce the ambiguity. With all variables included, there is a substantial elasticity of net spending with respect to the tax price (although estimated with a standard error that is as large as the coefficient), while with the restricted set of regressors the elasticity is small and totally insignificant.

The large standard errors and the sensitivity of these results to the set of included regressors imply that the estimated parameters must be interpreted with great caution. The key unambiguous finding is that deductibility has a substantial effect on the amount of personal deductible taxes paid to state and local governments. The effect of deductibility on the amount of other revenue collected by state and local governments is more uncertain. The current estimates do not permit rejecting the conclusion that deductibility has no effect on other types of revenue and therefore increases net spending by the same amount that it raises personal taxes. But the estimates based on the set of significant regressors support the alternative view that deductibility induces state and local governments to substitute personal taxes for other revenue sources almost completely, leaving total spending unchanged. If this view is correct, eliminating deductibility would cause "other revenue" to rise by as much as personal taxes are reduced. Until additional evidence is available, it seems best to recognize that both responses are plausible and consistent with the existing data.

\section{Effects of Deductibility on Federal Tax Revenue}

The present analysis has important implications about the effect of deductibility on federal tax revenue and therefore about the efficiency of deductibility as a way of increasing state and local spending. This section discusses the effect of deductibility on federal revenue, and Section VII considers the efficiency of deductibility as a means of increasing state and local spending.

As we noted above, the Treasury in 1984 proposed eliminating the deductibility of state and local personal taxes. The Treasury predicted that this change would raise $\$ 40$ billion in fiscal year 1990 . As such, the elimination of deductibility was the largest single source of increased revenue in the administration's tax reform plan.

The research presented here implies that eliminating deductibility might not produce anything like the amount of additional revenue that the Treasury predicted and might actually cause a fall in total tax revenue. The reason is that eliminating deductibility could cause state and local governments to switch some of their revenue from individ- 
uals - where each dollar of state and local tax payment has a relatively small impact on federal tax receipts-to corporations, where those same state and local tax payments have a much larger impact on federal tax revenue. If eliminating deductibility causes a large enough shift from personal taxes to taxes and fees paid by businesses, the Treasury could actually lose revenue by eliminating deductibility.

Consider more specifically the situation in 1984 and the implications of the estimates presented in Section V. The Treasury estimated that the deduction of state and local personal taxes (including income, sales, and property taxes) reduced federal revenue by $\$ 29.9$ billion in fiscal year 1984 and $\$ 32.4$ billion in fiscal year 1985 ; we will take the revenue loss for calendar year 1984 to be $\$ 30.5$ billion. If deductibility had been eliminated for 1984 and if state and local governments did not alter their business taxes or fees, federal revenue would have increased by $\$ 30.5$ billion.

In contrast, the estimates based on the set of significant regressors presented in column 3 of table 1 imply that eliminating deductibility would increase the "other state and local revenue" as a proportion of personal income by 0.20 times the resulting change in the federal tax price of currently deductible personal taxes. The average federal tax price in the sample used to estimate those behavioral equations was 0.92 ; eliminating deductibility would raise the federal tax price by 0.08 and would therefore increase other state and local revenue by 1.60 percent of personal income. Since personal income in 1984 was $\$ 3,012$ billion, this represents a $\$ 48$ billion increase in other state and local revenue. (Note that since the decrease in personal taxes implied by the estimated coefficient of -0.24 is equivalent to $\$ 58$ billion in 1984, the increase in other state and local revenue would offset 83 percent of the personal tax revenue lost by state and local governments.)

The impact on federal tax receipts of the increase in other state and local revenue depends on the nature of the increase. If these additional revenues are paid by businesses in the form of higher taxes or increased fees, the federal government would lose approximately 46 percent of the rise in other state and local revenue through lower corporate tax receipts, or $\$ 22$ billion of reduced corporate tax receipts. In addition, the reduction in net corporate income would mean reduced dividends and other personal capital income and therefore a further reduction in personal tax payments to the federal government. The combination of the decreased corporate and personal federal taxes that results from the induced increase in other state and local revenue would thus offset more than 70 percent and possibly more than 100 percent of the direct increase in federal revenue that results from eliminating the personal deduction. 
In practice, the offset to the direct increase in federal revenue might be smaller than this because at least some of the increased other state and local revenue would be in the form of greater charges to households for services provided by state and local governments. The analysis is also complicated by the fact that businesses might in part respond to increased state and local taxes and fees by reducing real wages. To that extent, the relevant tax rate is not the corporate 46 percent rate but the personal rate on wage and salary income.

There is, however, an important reason why the calculations presented above may understate the adverse effect on federal revenue of a shift in the composition of state and local revenue. The parameter estimates from Section $\mathrm{V}$ used to derive the shift in the composition of state and local revenue are based on interstate differences in the federal tax price at a point in time. A change in federal tax deductibility that affects all states equally is more likely to induce an increase in taxes on businesses than the same size difference in tax rates between two states. If one state raises its tax on businesses because it has a higher federal tax price for personal state and local taxes than the neighboring states, it is likely to drive some business away, thereby reducing its tax base and decreasing the demand for local labor. But if all states are faced with an increased federal tax price for personal state and local taxes because of a change in deductibility, they can all simultaneously raise their taxes on businesses without concern about driving business away.

All these considerations make it impossible to provide a precise estimate of the likely effect on federal revenue of eliminating deductibility. But they do make it clear that an induced shift in the composition of state and local taxation in response to the elimination of deductibility could reduce substantially, and might even more than fully eliminate, the prospective increase in federal personal income tax revenue. As a minimum, the analysis in this paper shows that it would be unwise for the federal government to assume that eliminating the deductibility of state and local taxes would increase federal tax receipts.

\section{The Cost-Effectiveness of Grants and Tax Deductibility}

The low (or possibly negative) cost to the federal government of the deductibility of state and local taxes implies that deductibility may be a very cost-effective way for the federal government to stimulate additional spending by state and local governments. This conclusion runs counter to the conventional assertion that deductibility is a high-cost 
way of stimulating state and local spending. ${ }^{14}$ This section illustrates how deductibility may be more cost-effective than federal grants in raising state and local spending.

The coefficient estimates of Section $V$ (for the restricted set of regressors estimated by the IV procedure) imply that deductibility increases the ratio of net state and local spending to personal income by $-0.04(-0.08)=0.0032$. What is the cost to the federal government of achieving this increase and how does it compare with the cost of other policies that may achieve an equal increase in state and local spending?

The same data imply that the ratio of personal deductible taxes to personal income is 0.075 . Since the effective tax rate (reflecting the extent of itemization and the marginal tax rate of itemizers) at which this is deducted is 0.08 , the resulting federal revenue loss is 0.60 percent of personal income. Against this must be offset the extra revenue that the federal government collects from businesses because deductibility induces state and local governments to tax businesses more lightly and from individual shareholders and creditors because of the increased net-of-tax income of businesses. The relevant parameter estimate implies that deductibility reduces other state and local revenue as a fraction of personal income by $0.20(0.08)=0.0160$. If a fraction $b$ of this reduction in other state and local revenue would otherwise have been paid by businesses and deducted against a federal tax rate of 0.46 percent, deductibility would increase federal revenue from businesses as a fraction of personal income by $0.46(0.0160) b=0.00746$.

The net cost of deductibility to the federal government, expressed as a fraction of personal income, is therefore $0.0060-0.0074 b$. If all the other state and local revenue is raised by taxes on businesses $(b=$ 1), deductibility has a negative cost to the federal government. But even if only half of the other state and local revenue is raised from businesses, the net cost of deductibility is 0.23 percent of personal income or $\$ 6.9$ billion at 1984 levels. Since deductibility raises spending by 0.32 percent of personal income, the cost-effectiveness of deductibility can be expressed as $0.32 / 0.23=\$ 1.39$ of increased state and local spending per dollar of net federal cost. Similarly, if twothirds of the other state and local revenue is raised from businesses, the cost-effectiveness of deductibility rises to $0.320 / .107=\$ 3.00 .^{15}$

What is the net cost to the federal government of increasing state

\footnotetext{
${ }^{14}$ See Noto and Zimmerman (1984) for a recent example of this conventional conclusion.

${ }^{15}$ This ignores the additional personal taxes collected because of higher dividends and interest income. Omitting this relatively small effect tends to overstate the cost of deductibility.
} 
and local spending by block grants to state and local governments? Several studies have shown that federal block grants to state and local governments increase spending by less than a dollar but more than the amount that would be expected by a pure income effect. ${ }^{16}$ If the increased state and local spending per dollar of federal block grant is $s$, the state and local governments reduce their tax receipts by $1-s$ per dollar of federal block grant. If a fraction $p$ of this reduction is in personal taxes that would be deducted at effective marginal tax rate $m$ and, of the remainder, the fraction paid by businesses is $b$, a dollar of federal block grant raises the federal government's tax revenue by $(1-s)[p m+(1-p)(.46 b)]$. The increase in state and local spending per dollar of cost to the federal government is thus $s /\{1-(1$ $-s)[p m+(1-p)(.46 b)]\}$. For example, using the average observed values of $p=0.65$ and $m=0.08$ and assuming $s=0.3$ and $b=0.5$ implies that this cost-effectiveness ratio is only $\$ 0.33$ of increased state and local spending per dollar of net federal cost. Even if each dollar of federal block grant raised state and local spending by a full dollar, the cost-effectiveness ratio would rise to only one dollar of increased local spending per dollar of federal cost.

Federal grants can be more cost-effective than tax deductibility only if the federal grants are matching grants that increase state and local spending by substantially more than one dollar for every dollar of federal grant. For example, if each dollar of federal matching grant raised state and local spending by $\$ 2.00$, the cost-effectiveness ratio becomes $\$ 1.77$ of increased state and local spending per net dollar of federal cost when $b=0.5$. But even with this very powerful matching effect, with the current illustrative numbers the federal matching grant is more costly than deductibility per dollar of increased state and local spending as long as $b$ is greater than 0.57 .

These calculations imply that substituting direct block grants or matching grants for deductibility could increase the cost to the federal government of achieving the current level of state and local spending. It is likely that federal grants to state and local governments can be rationalized only as a way to increase spending beyond the level that is achieved by deductibility or to alter the distribution of spending among states and program areas, or to redistribute income geographically.

\section{Conclusion}

This paper has examined the effect of the federal deductibility of state and local taxes on the fiscal behavior of state and local govern-

${ }^{16}$ See Inman (1979) and Rubinfeld (1986) for summaries of these studies. 
ments. Although there are substantial uncertainties about the empirical results, the evidence indicates that deductibility may affect the way that state and local governments finance their spending as well as the overall level of spending. More specifically, in states in which federal deductibility implies a relatively low cost of using deductible personal taxes (including income, sales, and property taxes), there may be substantially greater reliance on those taxes and less reliance on business taxes and other revenue sources.

This effect of deductibility on the state and local financial mix implies that deductibility may have a much lower cost to the federal government than has previously been assumed. Indeed, if deductibility causes a large enough shift of financing from business taxes to personal taxes, deductibility may actually raise federal tax receipts. The analysis also implies that deductibility may be a more costeffective way than direct grants to raise the general level of state and local government spending.

The present study used the individual tax return data in the NBER TAXSIM model to calculate federal tax prices for itemizers and other taxpayers in each state. The econometric analysis recognized that the federal tax price is endogenous (because it reflects the state and local spending decisions) and therefore used a consistent instrumental variable procedure. This use of instrumental variable estimation exacerbates the difficulty of making precise estimates from the data. The relatively large standard errors indicate the need for caution in interpreting the point estimates.

There are several directions in which the current work could usefully be pursued. Combining cross sections for two or more years could improve the precision of the parameter estimates. A more disaggregated analysis of the responsiveness of different types of revenue sources would make it possible to calculate the federal cost of deductibility more accurately. This could usefully be paralleled by a disaggregated analysis of spending.

But as of now, the analysis and data suggest that it would be wrong to assume that eliminating federal deductibility would substantially increase federal revenue or that substituting block grants for deductibility would permit the current level of state and local spending to be maintained at lower cost to the federal government. 


\section{Appendix}

TABLE A 1

Federal Tax Price and Related Statistics, 1979

\begin{tabular}{|c|c|c|c|}
\hline & $\begin{array}{c}\text { Federal } \\
\text { Tax Price }\end{array}$ & $\begin{array}{l}\text { Proportion } \\
\text { of Taxpayers } \\
\text { Who Itemize }\end{array}$ & $\begin{array}{c}\text { Federal } \\
\text { Tax Price } \\
\text { for Itemizers }\end{array}$ \\
\hline Alabama & .94 & .22 & .72 \\
\hline Alaska & .87 & .38 & .67 \\
\hline Arizona & .92 & .32 & .76 \\
\hline Arkansas & .94 & .25 & .75 \\
\hline California & .90 & .36 & .73 \\
\hline Colorado & .89 & .42 & .74 \\
\hline Connecticut & .91 & .31 & .73 \\
\hline Delaware & .95 & .18 & .70 \\
\hline Florida & .94 & .24 & .76 \\
\hline Georgia & .92 & .29 & .73 \\
\hline Hawaii & .93 & .27 & .72 \\
\hline Idaho & .91 & .38 & .76 \\
\hline Illinois & .92 & .27 & .71 \\
\hline Indiana & .93 & .24 & .72 \\
\hline Iowa & .93 & .23 & .71 \\
\hline Kansas & .93 & .28 & .73 \\
\hline Kentucky & .93 & .26 & .74 \\
\hline Louisiana & .94 & .19 & .71 \\
\hline Maine & .95 & .19 & .74 \\
\hline Maryland & .89 & .36 & .69 \\
\hline Massachusetts & .92 & .32 & .74 \\
\hline Michigan & .87 & .44 & .71 \\
\hline Minnesota & .92 & .32 & .74 \\
\hline Mississippi & .95 & .20 & .73 \\
\hline Missouri & .94 & .22 & .74 \\
\hline Montana & .93 & .32 & .78 \\
\hline Nebraska & .94 & .24 & .73 \\
\hline Nevada & .93 & .26 & .79 \\
\hline New Hampshire & .95 & .19 & .74 \\
\hline New Jersey & .92 & .28 & .70 \\
\hline New Mexico & .94 & .21 & .73 \\
\hline New York & .90 & .35 & .73 \\
\hline North Carolina & .93 & .24 & .72 \\
\hline North Dakota & .93 & .27 & .75 \\
\hline Ohio & .93 & .23 & .71 \\
\hline OkJahoma & .92 & .29 & .74 \\
\hline Oregon & .91 & .34 & .73 \\
\hline Pennsylvania & .93 & .26 & .73 \\
\hline Rhode Island & .92 & .28 & .71 \\
\hline South Carolina & .92 & .30 & .74 \\
\hline South Dakota & .97 & .14 & .75 \\
\hline Tennessee & .94 & .22 & .73 \\
\hline Texas & .93 & .22 & .70 \\
\hline Utah & .92 & .31 & .75 \\
\hline Vermont & .94 & .21 & .72 \\
\hline Virginia & .91 & .32 & .70 \\
\hline Washington & .93 & .24 & .70 \\
\hline West Virginia & .93 & .26 & .72 \\
\hline Wisconsin & .91 & .34 & .74 \\
\hline Wyoming & .95 & .17 & .70 \\
\hline
\end{tabular}

Source. - Authors' calculations using NBER TAXSIM model for 1979 
TABLE A2

Federal Tax Price Instruments, 1979

\begin{tabular}{|c|c|c|c|}
\hline & $\begin{array}{c}\text { Average } \\
\text { Dollar } \\
\text { Tax Price }\end{array}$ & $\begin{array}{c}\text { Synthetic } \\
\text { Proportion } \\
\text { of Itemizers }\end{array}$ & $\begin{array}{c}\text { Average Dollar } \\
\text { Tax Price } \\
\text { for Itemizers }\end{array}$ \\
\hline Alabama & .93 & .25 & .73 \\
\hline Alaska & .87 & .38 & .66 \\
\hline Arizona & .92 & .25 & .73 \\
\hline Arkansas & .92 & .29 & .73 \\
\hline California & .91 & .30 & .71 \\
\hline Colorado & .91 & .30 & .71 \\
\hline Connecticut & .91 & .31 & .70 \\
\hline Delaware & .93 & .23 & .72 \\
\hline Florida & .93 & .25 & .72 \\
\hline Georgia & .92 & .28 & .72 \\
\hline Hawaii & .92 & .27 & .72 \\
\hline Idaho & .92 & .30 & .73 \\
\hline Illinois & .90 & .32 & .70 \\
\hline Indiana & .91 & .32 & .72 \\
\hline Iowa & .91 & .29 & .71 \\
\hline Kansas & .91 & .31 & .71 \\
\hline Kentucky & .93 & .24 & .72 \\
\hline Louisiana & .92 & .28 & .71 \\
\hline Maine & .94 & .23 & .74 \\
\hline Maryland & .90 & .31 & .69 \\
\hline Massachusetts & .92 & .27 & .71 \\
\hline Michigan & .89 & .37 & .69 \\
\hline Minnesota & .93 & .26 & .72 \\
\hline Mississippi & .94 & .22 & .74 \\
\hline Missouri & .93 & .26 & .72 \\
\hline Montana & .92 & .28 & .73 \\
\hline Nebraska & .92 & .29 & .71 \\
\hline Nevada & .93 & .26 & .71 \\
\hline New Hampshire & .93 & .25 & .72 \\
\hline New Jersey & .91 & .30 & .69 \\
\hline New Mexico & .92 & .29 & .73 \\
\hline New York & .92 & .28 & .70 \\
\hline North Carolina & .93 & .25 & .73 \\
\hline North Dakota & .93 & .27 & .73 \\
\hline Ohio & .92 & .29 & .71 \\
\hline OkJahoma & .91 & .31 & .72 \\
\hline Oregon & .91 & .32 & .72 \\
\hline Pennsylvania & .92 & .29 & .71 \\
\hline Rhode Island & .91 & .29 & .70 \\
\hline South Carolina & .93 & .26 & .73 \\
\hline South Dakota & .93 & .24 & .72 \\
\hline Tennessee & .93 & .27 & .72 \\
\hline Texas & .92 & .29 & .70 \\
\hline Utah & .93 & .24 & .73 \\
\hline Vermont & .93 & .26 & .73 \\
\hline Virginia & .91 & .30 & .70 \\
\hline Washington & .91 & .30 & .70 \\
\hline West Virginia & .90 & .34 & .70 \\
\hline Wisconsin & .91 & .30 & .71 \\
\hline Wyoming & .91 & .29 & .70 \\
\hline
\end{tabular}

Soukce-Authors' calculations using NBER TAXSIM model for 1979. 
TABLE A3

Effects of Federal Deductibility on State and local Taxes and Spending: Ratio Specification

\begin{tabular}{|c|c|c|c|}
\hline & $\begin{array}{c}\text { Personal } \\
\text { Taxes }\end{array}$ & $\begin{array}{c}\text { Other } \\
\text { State } \\
\text { and } \\
\text { Local } \\
\text { Revenue }\end{array}$ & $\begin{array}{c}\text { Net } \\
\text { State } \\
\text { and } \\
\text { Local } \\
\text { Spending }\end{array}$ \\
\hline Tax price & $\begin{array}{c}-.418 \\
(.280)\end{array}$ & $\begin{array}{r}-.155 \\
(.319)\end{array}$ & $\begin{array}{c}-.573 \\
(.367)\end{array}$ \\
\hline Pupils per capita & $\begin{array}{c}57.288 \\
(26.963)\end{array}$ & $\begin{array}{c}-77.748 \\
(30.641)\end{array}$ & $\begin{array}{r}-20.460 \\
(35.248)\end{array}$ \\
\hline Road mileage per capita & $\begin{array}{r}-.003 \\
(.005)\end{array}$ & $\begin{array}{r}-.001 \\
(.005)\end{array}$ & $\begin{array}{r}-.004 \\
(.006)\end{array}$ \\
\hline Nonwhite (\%) & $\begin{array}{r}-.019 \\
(.044)\end{array}$ & $\begin{array}{r}-.042 \\
(.049)\end{array}$ & $\begin{array}{r}-.060 \\
(.057)\end{array}$ \\
\hline Urban (\%) & $\begin{array}{c}-.018 \\
(.024)\end{array}$ & $\begin{array}{c}.043 \\
(.028)\end{array}$ & $\begin{array}{l}.025 \\
(.032)\end{array}$ \\
\hline Poverty (\%) & $\begin{array}{c}.685 \\
(.441)\end{array}$ & $\begin{array}{c}.056 \\
(502)\end{array}$ & $\begin{array}{c}.741 \\
(.577)\end{array}$ \\
\hline Aged (\%) & $\begin{array}{c}.535 \\
(.221)\end{array}$ & $\begin{array}{r}-.650 \\
(.251)\end{array}$ & $\begin{array}{r}-.115 \\
(.289)\end{array}$ \\
\hline Homeowners (\%) & $\begin{array}{c}-.187 \\
(.060)\end{array}$ & $\begin{array}{l}.179 \\
(.068)\end{array}$ & $\begin{array}{r}-.008 \\
(.078)\end{array}$ \\
\hline \multicolumn{4}{|l|}{ Family income: } \\
\hline $7,500-15,000$ & $\begin{array}{c}.689 \\
(.578)\end{array}$ & $\begin{array}{c}-.261 \\
(.656)\end{array}$ & $\begin{array}{r}.428 \\
(.755)\end{array}$ \\
\hline $15,000-25,000$ & $\begin{array}{l}.623 \\
(.471)\end{array}$ & $\begin{array}{r}-.312 \\
(.535)\end{array}$ & $\begin{array}{l}.311 \\
(.616)\end{array}$ \\
\hline $25,000-35,000$ & $\begin{array}{l}1.009 \\
(.632)\end{array}$ & $\begin{array}{c}.314 \\
(.718)\end{array}$ & $\begin{array}{l}1.323 \\
(.826)\end{array}$ \\
\hline $35,000-50,000$ & $\begin{array}{l}.534 \\
(.648)\end{array}$ & $\begin{array}{r}-1.181 \\
(.736)\end{array}$ & $\begin{array}{c}-.646 \\
(.847)\end{array}$ \\
\hline $50,000+$ & $\begin{array}{l}.470 \\
(.641)\end{array}$ & $\begin{array}{c}.055 \\
(.729)\end{array}$ & $\begin{array}{c}.526 \\
(.839)\end{array}$ \\
\hline Variance of AGI & $\begin{array}{c}-.007 \\
(.019)\end{array}$ & $\begin{array}{c}.014 \\
(.022)\end{array}$ & $\begin{array}{c}.007 \\
(.025)\end{array}$ \\
\hline Skew of AGI & $\begin{array}{r}-.012 \\
(.193)\end{array}$ & $\begin{array}{c}-.094 \\
(.220)\end{array}$ & $\begin{array}{r}-.106 \\
(.253)\end{array}$ \\
\hline Dividends and interest per dollar of AGI & $\begin{array}{c}-.045 \\
(.427)\end{array}$ & $\begin{array}{c}.734 \\
(.485)\end{array}$ & $\begin{array}{l}.689 \\
(.558)\end{array}$ \\
\hline Capital gains per dollar of AGI & $\begin{array}{c}.003 \\
(.024)\end{array}$ & $\begin{array}{c}-.043 \\
(.029)\end{array}$ & $\begin{array}{r}-.039 \\
(.032)\end{array}$ \\
\hline Percentage married & $\begin{array}{c}-2.126 \\
(4.379)\end{array}$ & $\begin{array}{r}-1.950 \\
(4.976)\end{array}$ & $\begin{array}{r}-4.076 \\
(5.725)\end{array}$ \\
\hline Constant & $\begin{array}{c}-23.122 \\
(46.926)\end{array}$ & $\begin{array}{c}46.027 \\
(53.326)\end{array}$ & $\begin{array}{c}22.906 \\
(61.344)\end{array}$ \\
\hline Standard error of regression & 1.167 & 1.326 & 1.525 \\
\hline
\end{tabular}

Nore- The dependent variable in each equation is measured as a ratio to personal income. All equations are estimated by an instrumental variable procedure Standard errors are shown in parentheses. 


\section{References}

Bartlett, Bruce. "The Case for Eliminating Deductibility of State and Local Taxes." Tax Notes 28 (September 2, 1985): 1121-25.

Billman, Brookes D., Jr., and Cunningham, Noel B. "Nonbusiness State and Local Taxes: The Case for Deductibility." Tax Notes 28 (September 2, 1985): 1105-20.

Break, George F. "Commentary." In American Domestic Priorities: An Economic Appraisal, edited by John M. Quigley and Daniel L. Rubinfeld. Berkeley: Univ. California Press, 1985.

Bridges, Benjamin, Jr. "Deductibility of State and Local Nonbusiness Taxes under the Federal Individual Income Tax." Nat. Tax J. 19 (March 1966): 117.

Feldstein, Martin S. "Multicollinearity and the Mean Square Error of Alternative Estimators." Econometrica 41 (March 1973): 337-46.

, ed. Behavioral Simulation Methods in Tax Policy Analysis. Chicago: Univ. Chicago Press (for N.B.E.R.), 1983.

Feldstein, Martin S., and Metcalf, Gilbert E. "The Effect of Federal Deductibility on State and Local Taxes and Spending." Working Paper no. 1791. Cambridge, Mass.: N.B.E.R., January 1986.

Gramlich, Edward M. "The Deductibility of State and Local Taxes." Nat. Tax J. 38 (December 1985): 447-65. (a)

- "Reforming U.S. Federal Fiscal Arrangements." In American Domestic Priorities: An Economic Appraisal, edited by John M. Quigley and Daniel L. Rubinfeld. Berkeley: Univ. California Press, 1985. (b)

Hettich, Walter, and Winer, Stanley. "A Positive Model of Tax Structure." $J$. Public Econ. 24 (June 1984): 67-87.

Inman, Robert P. "The Fiscal Performance of Local Governments: An Interpretative Review." In Current Issues in Urban Economics, edited by Peter Mieszkowski and Mahlon Straszheim. Baltimore: Johns Hopkins Univ. Press, 1979.

- "Does Deductibility Influence Local Taxation?" Working Paper no. 1714. Cambridge, Mass.: N.B.E.R., October 1985.

- "Markets, Government, and the 'New' Political Economy." In Handbook of Public Economics, vol. 2, edited by Alan J. Auerbach and Martin S. Feldstein. Amsterdam: North-Holland, 1986.

Ladd, Helen F. "Federal Aid to State and Local Governments." In Federal Budget Policy in the 1980s, edited by Gregory B. Mills and John L. Palmer. Washington: Urban Inst., 1984.

Madalla, G. S. Econometrics. New York: McGraw-Hill, 1977.

Noto, Nonna A., and Zimmerman, Dennis. "Limiting State-Local Tax Deductibility in Exchange for Increased General Revenue Sharing: An Analysis of the Economic Effects." Senate Print no. 98-77. Washington: Government Printing Office, 1983.

- "Limiting State-Local Tax Deductibility: Effects among the States." Nat. Tax J. 37 (December 1984): 539-49.

Office of Management and Budget. "Special Analysis H: Federal Aid to State and Local Governments." In The Budget for Fiscal Year 1986. Washington: Government Printing Office, 1985.

Office of the President. The President's Tax Proposals to the Congress for Fairness, Growth, and Simplicity. No. 62-69. Washington: Government Printing Office, 1985. 
Phares, Donald. Who Pays State and Local Taxes? Cambridge, Mass.: Oelgeschlager, Gunn, and Hain, 1980.

Rubinfeld, Daniel L. "The Economics of the Local Public Sector." In Handbook of Public Economics, vol. 2, edited by Alan J. Auerbach and Martin S. Feldstein. Amsterdam: North-Holland, 1986.

U.S. Department of the Treasury. Tax Reform for Fairness, Simplicity and Economic Growth. Vol. 1. Washington: Government Printing Office, 1984.

Zimmerman, Dennis. "Resource Misallocation from Interstate Tax Exportation: Estimates of Excess Spending and Welfare Loss in a Median Voter Framework." Nat. Tax J. 36 (June 1983): 183-201. 